\title{
SOME RECONSIDERATIONS ON PENDANT-LEGGED BUDDHA IMAGES IN THE DVĀRAVATİ ARTISTIC TRADITION
}

\author{
Nicolas Revire \\ Université Paris 3-Sorbonne nouvelle \& Thammasat University, Bangkok; \\ nicolasrevire@hotmail.com
}

\begin{abstract}
The aim of this paper is to reassess some common ideas about a particular type of buddha image frequently found in Central Thailand during the ca. 7th- 8th centuries: the buddhas seated in the so-called "European fashion" or pendant-legged, often labeled pralambapādāsana in Sanskrit. While briefly dealing with iconographic questions-including the origins and meanings of this particular posture-this paper will also discuss the matter of terminology in relation to the royal symbolism conveyed by this iconography.
\end{abstract}

This preliminary study of the pendant-legged buddha images in the art of Dvāravatī is prompted by a simple observation that nothing substantial has been written thus far on the topic. There were certainly some works issued by pioneer scholars in the field which touched upon the subject but since then new evidence has emerged in Thailand and neighboring countries. $^{2}$ There is also the puzzling case of the four colossal buddhas, in the same posture, suspected to come from Wat Phra Men, Nakhon Pathom (Dhanit 1967) (Figure 1). I have already devoted a detailed analysis elsewhere (2008 and 2010). The buddhas sitting in the so-called "European fashion," i.e. seated with two legs hanging down, ${ }^{3}$ contrasts with the more traditional posture known as seated in the "Indian manner," or with legs crossed beneath the torso. This pendant leg posture is found not only in the Dvāravatī tradition but across Buddhist Asia circa the seventh and eighth centuries. In general, much attention has been given to the "Indian manner" and the standing posture, but the genesis and meanings associated with the pendant-leg position has been scarcely explored.

In the short format of the present paper, I will not attempt to deal with the controversial question of the identification of these images in Buddhist art. Suffice it to say that, generally speaking, they are believed to represent either the historical Buddha Sākyamuni ${ }^{4}$ or the future Buddha Maitreya, and on rare occasions they have even been identified as Buddha Vairocana. Each case depends on the unique cultural and archaeological context. ${ }^{5}$ It is readily acknowledged, however, that without textual evidence or epigraphy, it remains quite hazardous to identify such buddhas. Indeed, a buddha image remains a buddha image, conveying the ideals of the thirty-two major characteristics or lakșana, ${ }^{6}$ no matter if it is past, present or future, "historical" or "transcendental."

\section{A PECULIAR ICONOGRAPHY}

Broadly speaking, in the art of Dvāravatī, seated buddha images are few compared to standing ones. This assertion holds true for stone and bronze statues, but not necessarily the stucco or terra-cotta, whose total number are unknown. Seated buddha statues were either crossed-legged or with legs pendant. Such pendant-legged images are found in different materials and sizes and among several sites in what today constitutes roughly Central Thailand. ${ }^{7}$ They are of a peculiar type, belonging to what Dupont has called group T (1959: 273-274), and are seated with the right hand raised in the teaching gesture while the left one is often placed on the lap (in low-reliefs) or upon the knee (in the round). In fact, this iconography is not unique to Dvāravatī and there are similar Southeast Asian images, albeit only a few are extant. Interestingly enough, the examples seem to be equally numerous in eastern Asia (Revire Forthcoming).

Possibly one of the earliest Southeast Asian images of its kind is the small seated buddha from the Sòn Tho village, in the Trà Vinh Province, Southern Vietnam (Louis Malleret 1963, IV: 178-179, Plate 31; Nancy Tingley 2009a: 148149). This small stone buddha image, which I tend to date to the second half of the seventh century, offers close affinities in both style and iconography to those in the round from Nakhon Pathom. A large pendant-legged fragment belonging to a similar seated buddha has also appeared recently in Lower-Laos, near the site of Wat Phu (Lorrillard 2008: 121, 174 Figure 13) (Figures 2a-b). Furthermore, if we take into 


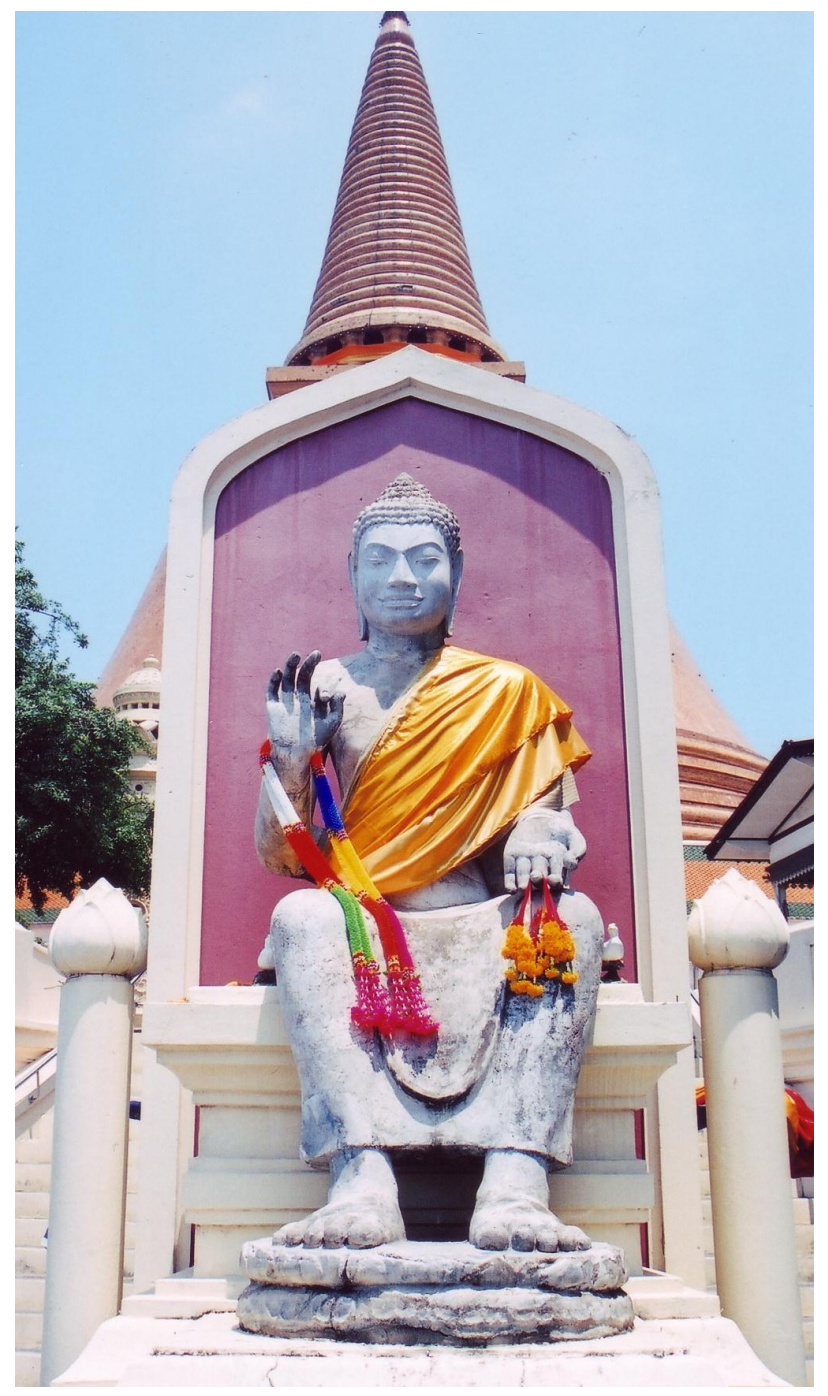

Figure 1. Pendant-Legged Buddha in vitarkamudrā, Stone, $7^{\text {th }}-8^{\text {th }}$ Century, Phra Pathom Chedi, Nakhon Pathom, Thailand

consideration the few extant models that seem to have reached the hands of private collectors, it is conceivable to assume that perhaps the diffusion of this iconography was once more important in the region. ${ }^{8}$ As for Burma, only a few small bronze images and terracotta plaques seem to depict this iconography (Mya 1961, II: Plates 53-54; Luce 1985, II: Figure 76b; Moore 2007: 20-21, 164, 198, 222), while in Java, there are more examples, not only in bronze (Fontein 1990: 183-185; Woodward 1988: Figure 12) but also stone (Figure 3). ${ }^{9}$ Is this iconography, however, unique to Southeast Asia?

Surprisingly, this iconographic feature - based on the right hand raised - is virtually absent from India, ${ }^{10}$ despite the fact that there are numerous examples of pendant-legged buddhas in Ajantā, Ellorā, Kaṇherī and other western Deccan caves (Figure 4), all performing the gesture of "Turning the Wheel of the Law" with both hands (dharmacakramudrā or dharmacakrapravartanamudrā) ${ }^{11}$ This latter hand gesture, however, is practically unknown in Dvāravatī iconography. ${ }^{12}$ In this context, it may be difficult to assume any direct influence from India to Thailand in regards to this iconography. ${ }^{13}$ On the other hand, the single teaching gesture (vitarkamudrā), or the "assurance" hand gesture (abhayamudrā), associated with the pendant-legged sitting posture, seemed to have been more popular not only in Central Thailand (Figure 5) and Java (Figure 3), but more significantly in China around the early Tang period (Figure 6) and Japan during the late Asuka or early Nara periods (e.g. Wong 2008:144 Figure 5.13 and Plates 13, 16, 17). The vitarkamudrā is also found in Central Asian wall paintings (Härtel et al. 1982: 56), where it seems to take prominence. Given this apparent iconographic tendency, it is quite reasonable to search for a prototype in Central or Eastern Asia in order to explain subsequent developments in Southeast Asian imagery.

A good candidate for the pendant-legged prototype of the Dvāravatī models could be found in China (e.g. Figure 6). For instance, on the basis of iconography and certain stylistic motifs, Hiram Woodward suggested that at least one Dvāravatī relief depicting the First Sermon with the pendantlegged buddha, right hand raised and left hand in lap, (Figure 7) may have been--consciously or not--inspired by some Chinese works around the year 700 (2003: 73-74). ${ }^{14}$ The iconographic combination just mentioned here is not found at a later period. In my opinion, strong affiliations with Dvāravatī pendant-legged buddhas might also be suggested for a seated buddha type from Longmen caves: the so-called "Udayana type" (Figure 8). These numerous buddha images have both legs hanging down and seem to display the same teaching gesture (vitarkamudrā) as the Dvāravatī ones. Many of the "Udayana" statues from Longmen are dated by inscriptions to circa 655-680 C.E. (McNair 2007: 99 Figure 5.3). Interestingly, Marylin Rhie observed a close relationship between these figures and those from Central Thailand, circa the seventh century (1988: 41-44). This connection with China and Longmen raises intriguing questions. Could these "Udayana buddha figures" with legs pendant refer to some now lost important icons in India or Gandhāra brought back to China by Xuanzang or other pilgrims in 645 C.E.? And could these refer to the myth of the first carved or painted buddha image for King Udayana (Carter 1990: 1 n. 2)? Whatever the case may be, uncertainty still remains as to how this iconography travelled to Southeast Asia and Dvāravatī around the seventh or eighth century. It would be an obvious suggestion that this was part of a cosmopolitan Buddhist "art style" at the time, given the mainland and maritime traffic on the Silk Road, but this 

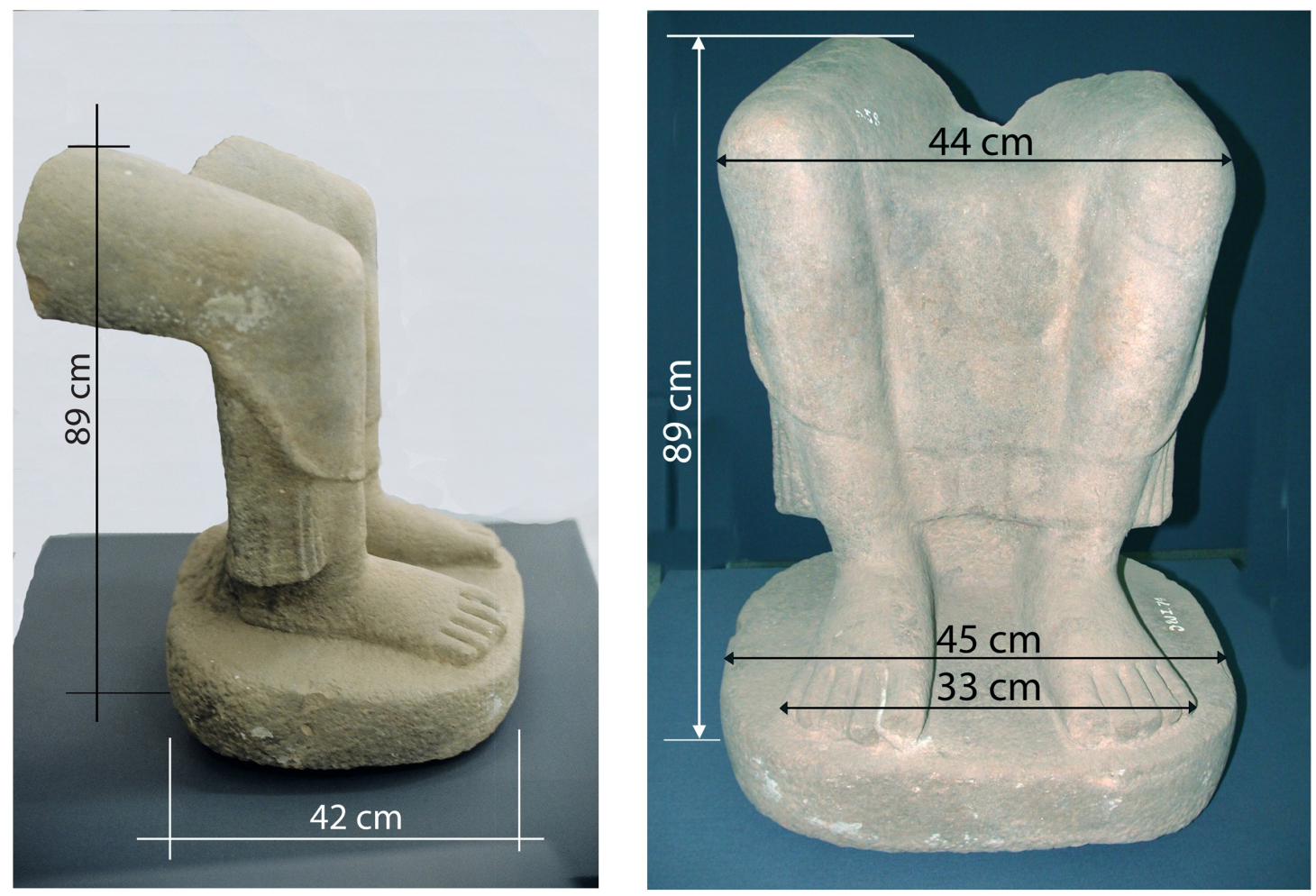

Figure 2. Buddha's Pendant Legs, Stone Fragment, $7^{\text {th }}-8^{\text {th }}$ Century (?), Wat Phu - Site Museum, Laos (Courtesy of Pierre Pichard). a) Side View. b) Front View.

assertion needs further documentation and research (Revire, forthcoming).

All told, these brief iconographic observations, if accepted, seem to place the date of the buddha images from close to the last decades of the seventh century or the early eighth century. ${ }^{15} \mathrm{We}$ will now turn to the controversial question of terminology for this posture.

\section{THE MATTER OF TERMINOLOGY}

Generally speaking, Sanskrit terminology is quite prevalent among art historians' descriptions of the buddha statues and their iconographies. Such vocabulary, however, has some inherent misconceptions. Firstly, we should be aware that the terms are neither indigenous to Southeast Asia or known to have been used in Dvāravatī (or in Gandhāra, Bhārhut, Mathurā, etc.) for that purpose. As Peter Skilling has observed:

"To use these terms might suggest that there was a standardized use of manuals or concepts of iconography - which remains to be demonstrated. The ' $m u d r \bar{a}$ ' terms, including the term ' $m u d r \bar{a}$ ' itself, are from Pāla or postPāla 'sädhana' texts known in North-Eastern India and translated into Tibetan. Of course, the terms may be used as reference but not, for me, as primary categories. In this I may go against art-historical traditions" (Personal communication 2008). ${ }^{16}$

In my view, the modern appellations of buddhas sitting pendant-legged may be similarly criticized. One traditionally distinguishes these buddha images by their seating, in the "European fashion" or "Western manner", as opposed to those seated in the more traditional "Indian manner", or crossed-legs. These categories, however, are the products of older scholarship and should be seriously reconsidered. Some even go as far as to speak of the "Chinese," the "Iranian" or "Gandhārian" posture on the simple tenet that this iconography seems to have found its origin in Greater Gandhāra and have spread in China (Frédéric 2001: $48 \mathrm{n}$. 16). But should an iconographic posture really be "ethnicized"? Besides, which among the several Sanskrit equivalents that are regularly given is more legitimate?

\section{THE "EUROPEAN" POSTURE VERSUS SANSKRIT TERMINOLOGY}

The term "European posture" made its first appearance at the end of the nineteenth century among European savants immersed in a colonial environment. As far as I have been 


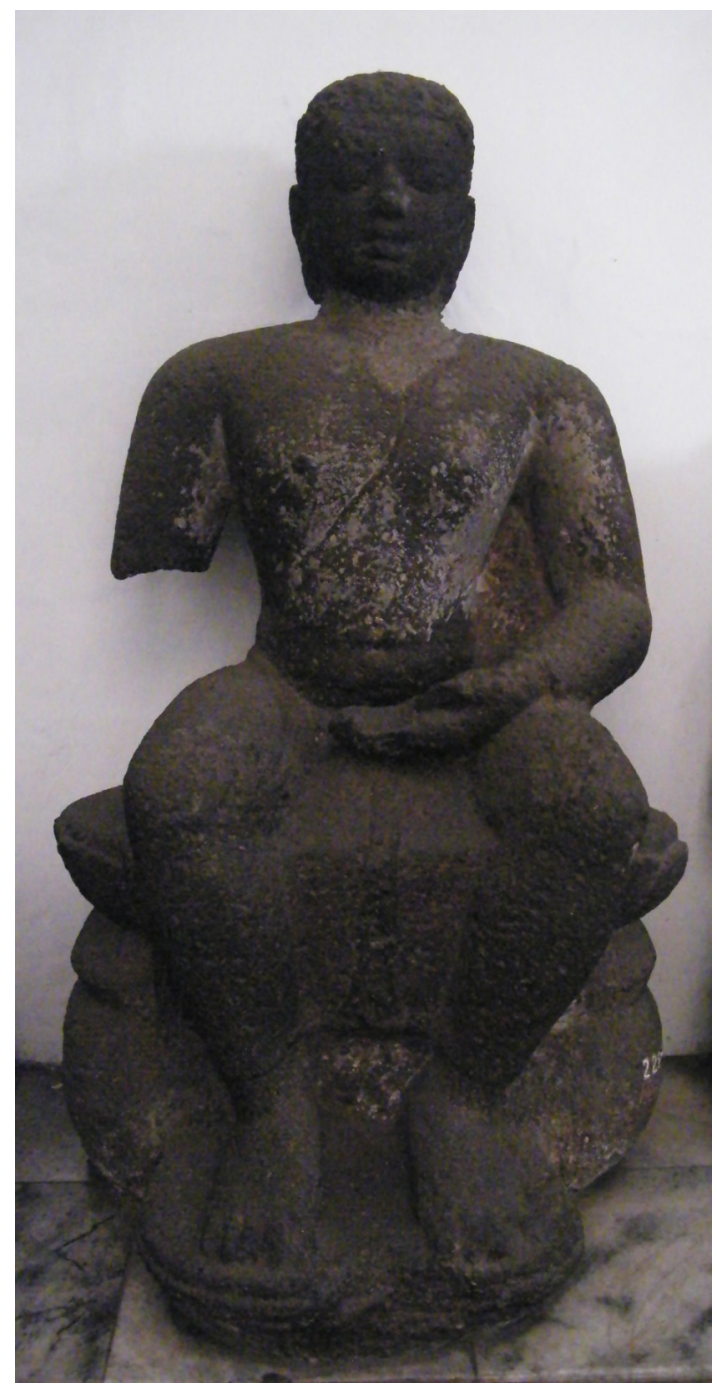

Figure 3. Pendant-Legged Buddha in abhaya- or vitarkamudrā, Stone, $8^{\text {th }}$ Century (?), Museum Nasional Indonesia, Jakarta

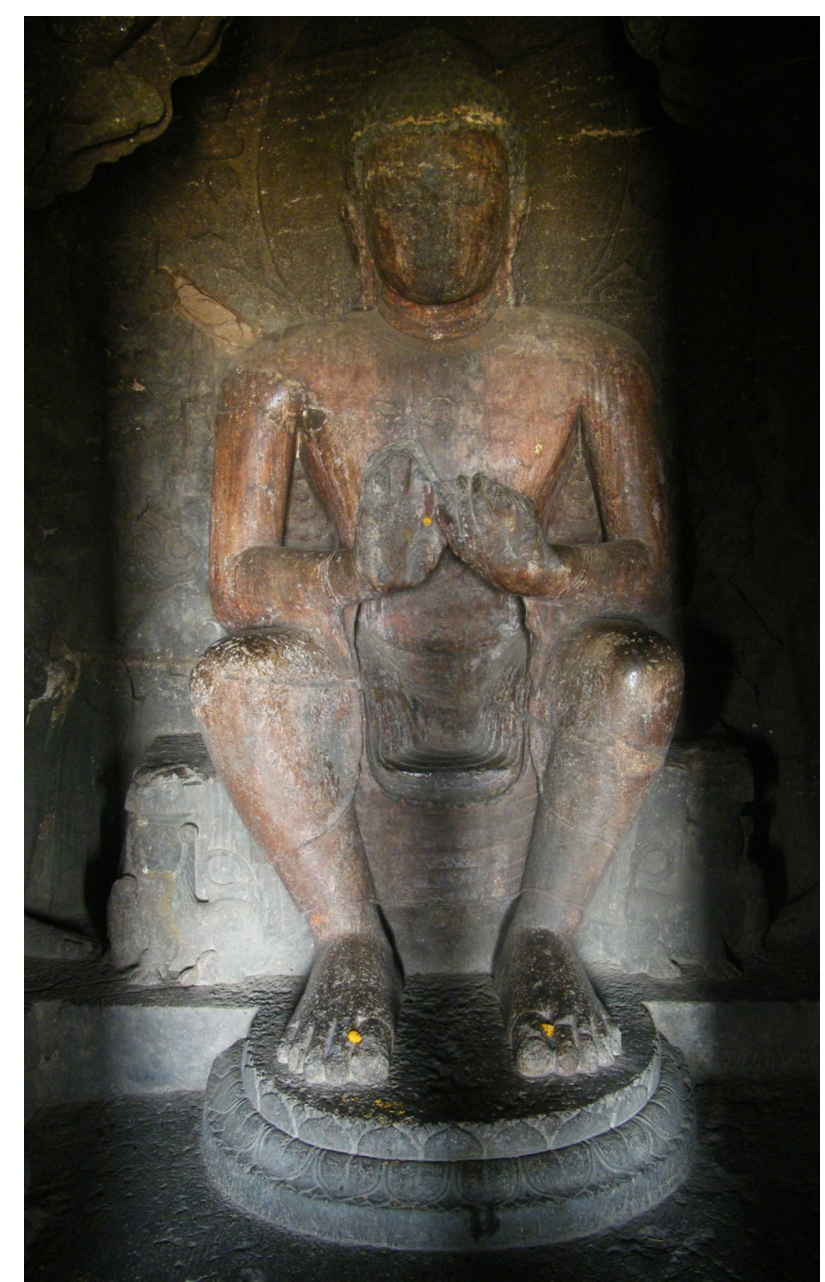

Figure 4. Pendant-Legged Buddha in dharmacakramudrā, High Relief, Stone, $\sigma^{\text {th }}-7^{\text {th }}$ Century (?), Aurangābād, Cave 6, India 


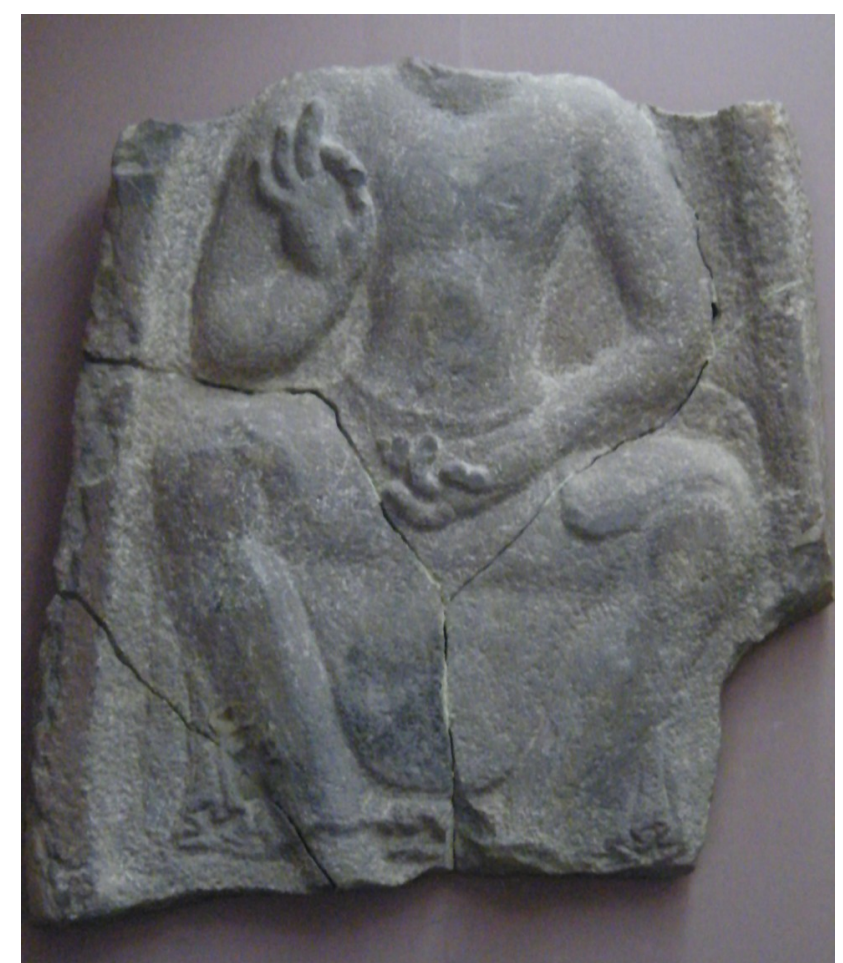

Figure 5. Pendant-Legged Buddha in vitarkamudrā, Low Relief Fragment, Stone, $7^{\text {th }}-8^{\text {th }}$ Century (?), Phimai National Museum, Thailand

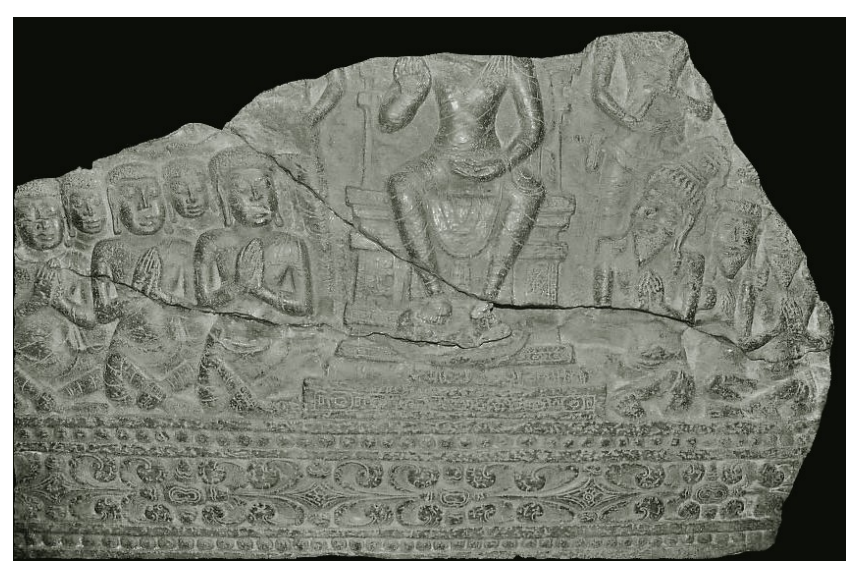

Figure 7. Enthroned Buddha in vitarkamudrā, Low Relief, Stone, $7^{\text {th }}-8^{\text {th }}$ Century, Phra Pathom Chedi National Museum, Nakhon Pathom, Thailand

Figure 8: King Udayana Buddha Images, High Relief, Stone, $7^{\text {th }}$ Century, Longmen Caves, China

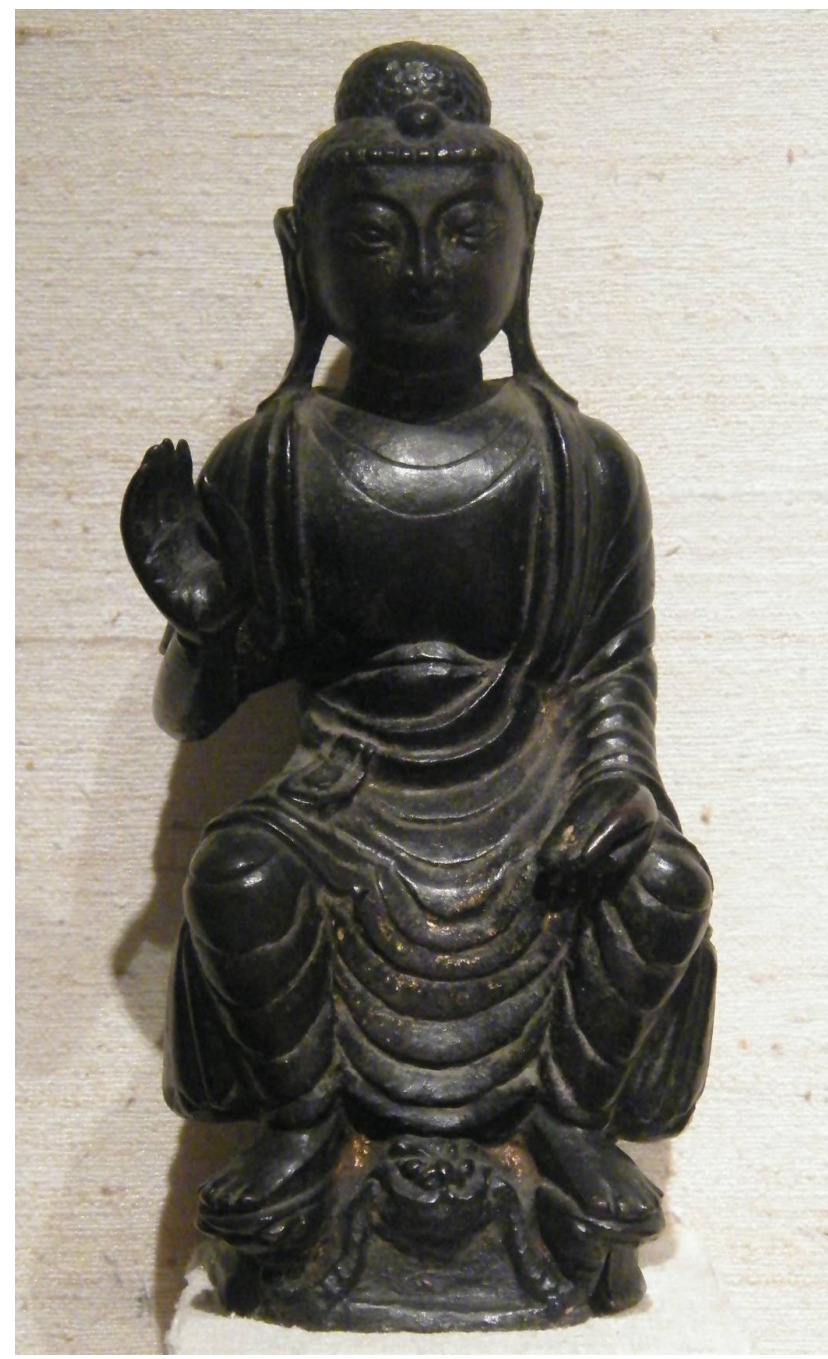

Figure 6. Pendant-Legged Buddha in abhayamudrā, Bronze, Tang Period Style, $7^{\text {th }}-8^{\text {th }}$ Century (?), Pacific Asia Museum, Pasadena, USA

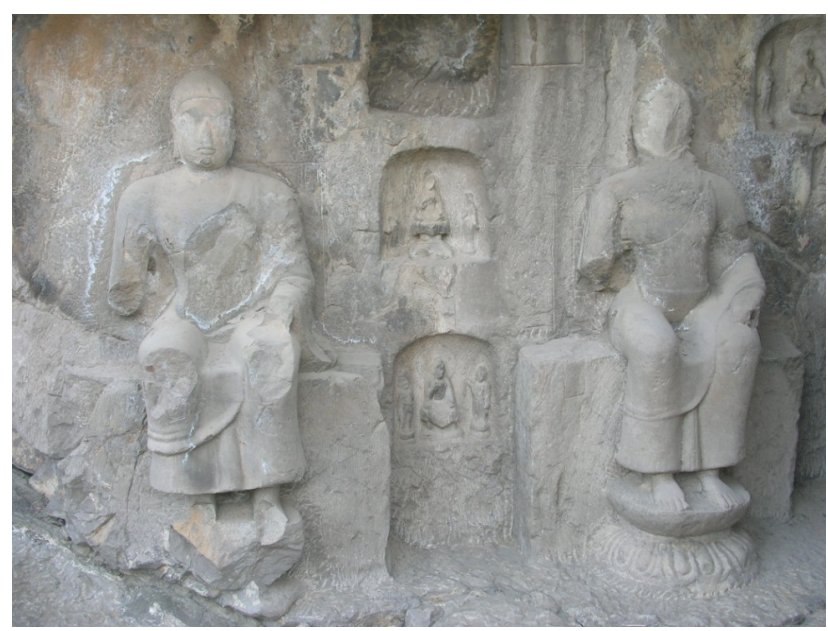


BULLETIN OF THE INDO-PACIFIC PREHISTORY ASSOCIATION 31, 2011

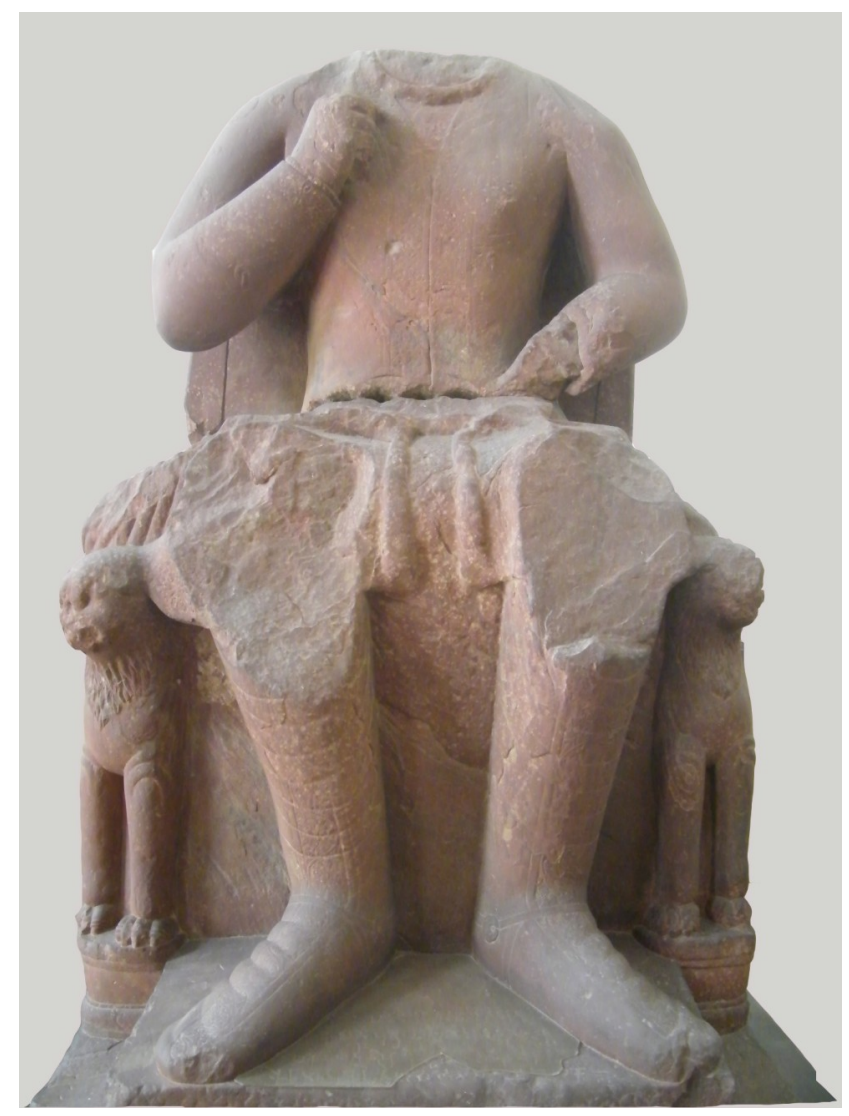

Figure 9. Kușāṇa Emperor (Vima Kadphises?) on a Throne, Stone, $1^{\text {st }}$ or $2^{\text {nd }}$ Century C.E., Mathurā Archaeological Museum, India

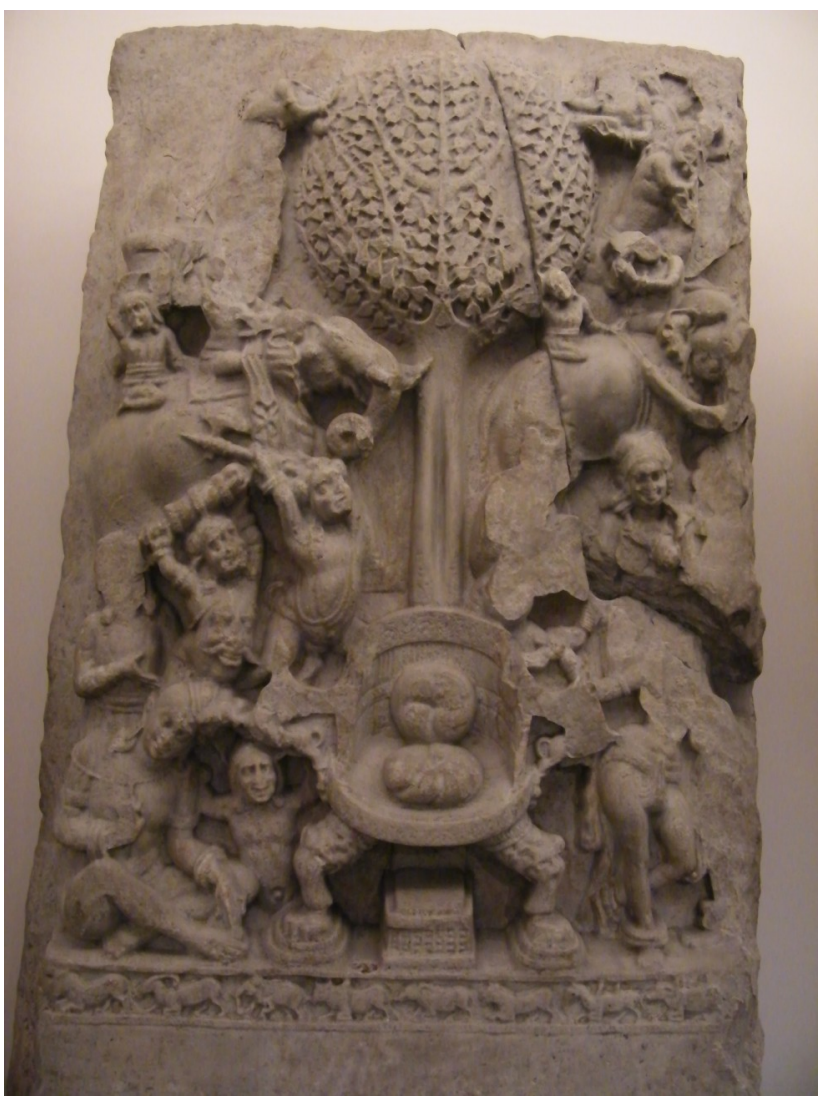

Figure 10. Empty Lion Throne with Buddha Footprints, Stone Slab, Amarāvatī style, $2^{\text {nd }}$ Century C.E., Musée Guimet, Paris, France 
REVIRE: RECONSIDERATIONS ON PENDANT-LEGGED BUDDHA IMAGES

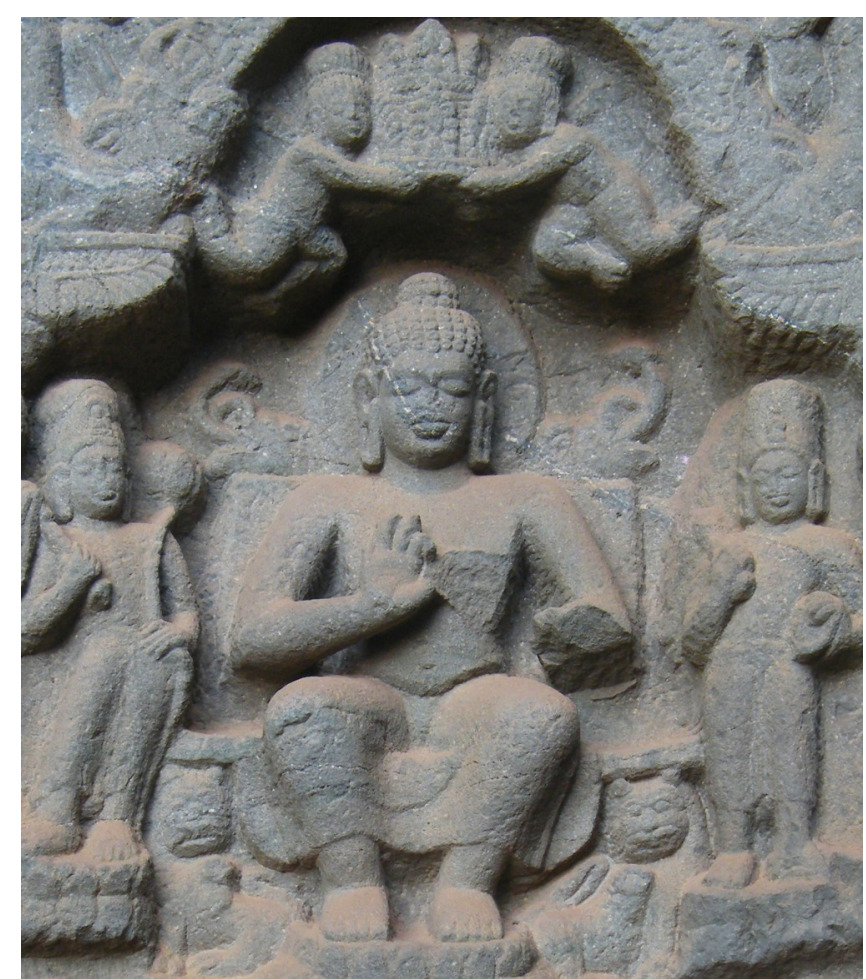

Figure 11. Enthroned Buddha (on Mount Meru?), Topped by Celestials carrying a Crown, High Relief, Stone, ca. $6^{\text {th }}$ Century, Karli (in situ), India

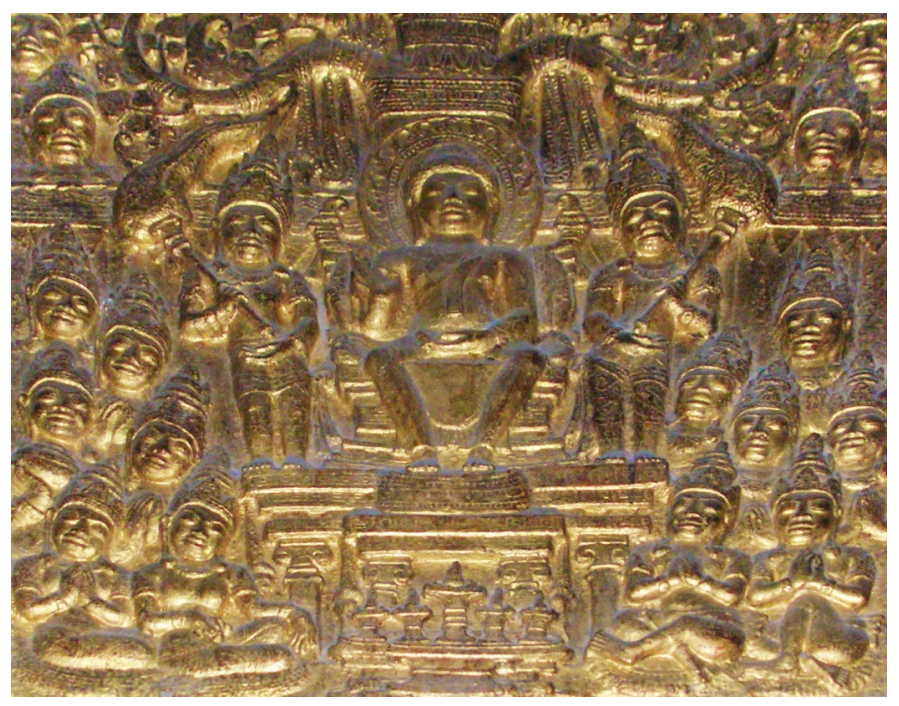

Figure 12. Enthroned Buddha in Trāyastrimśa, Low Relief, Stone, $7^{\text {th }}-8^{\text {th }}$ Century, Wat Suthat, Bangkok, Thailand

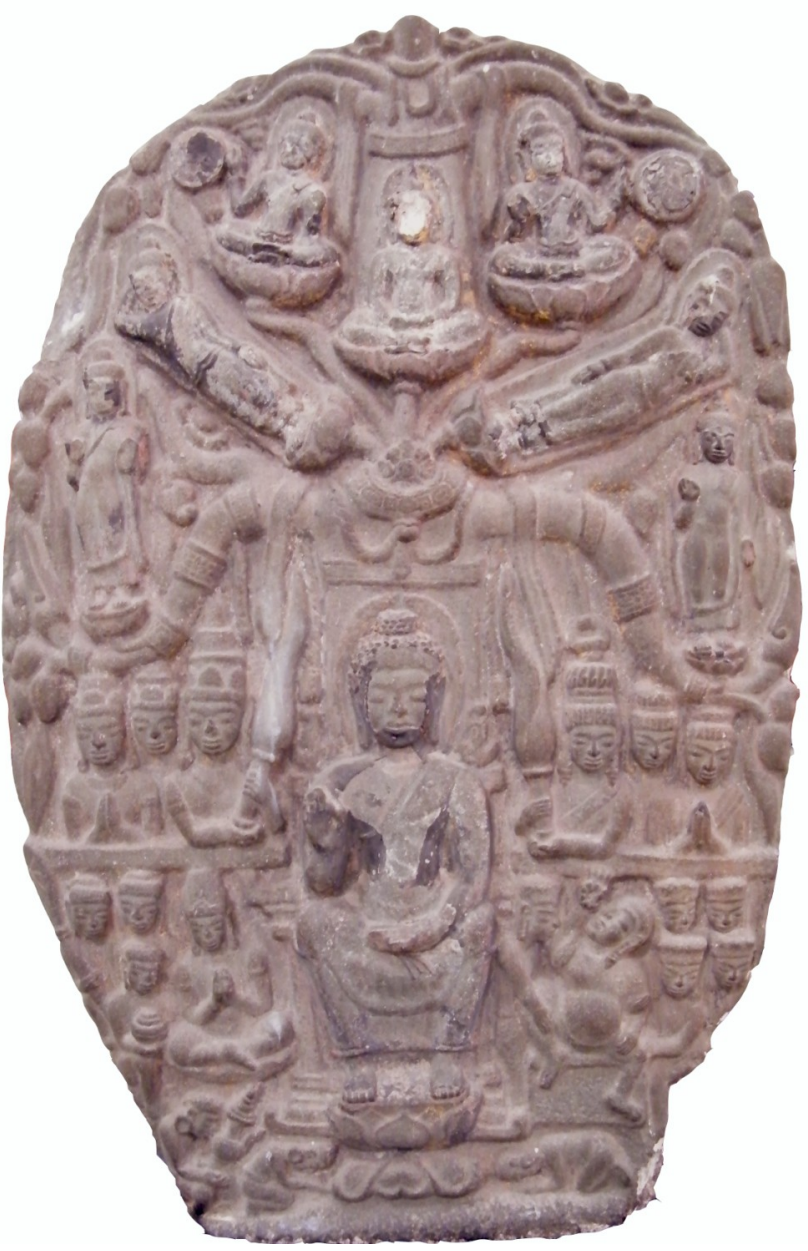

Figure 13. The Great Miracle at Śrāvastī, Low Relief, Stone, $7^{\text {th }}-8^{\text {th }}$ Century, Bangkok National Museum, Thailand 


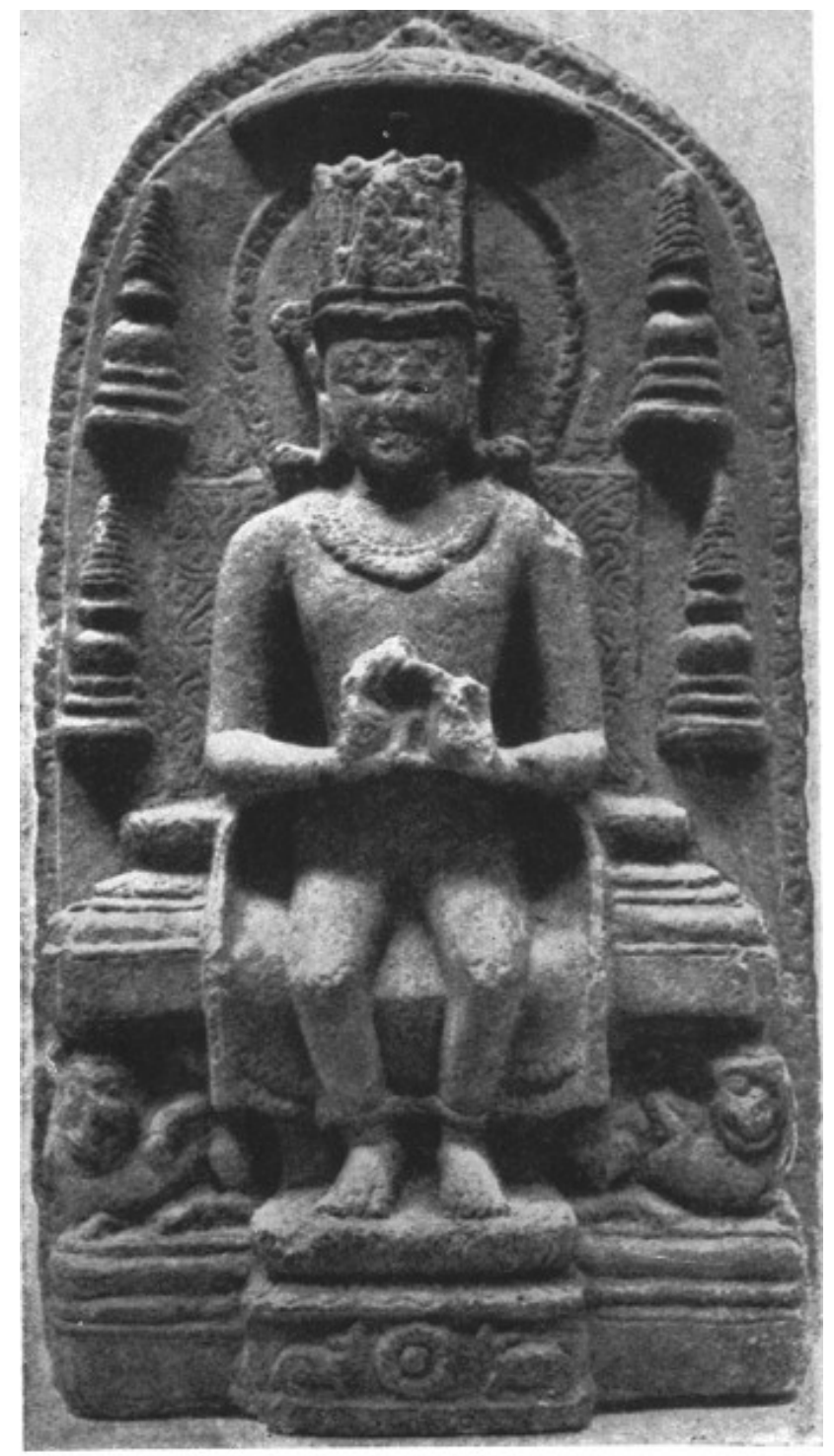

Figure 14. Crowned Buddha seated with Legs Pendant, High Relief, Stone, Pāla Period Style, $10^{\text {th }}-12^{\text {th }}$ Century (?), Boston Museum of Fine Arts, USA (Bourda 1949: 311 Figure 5)

able to trace, the earliest occurrence was probably penned by German Albert Grünwedel in his "Handbuch" entitled Buddhistische Kunst in Indien, first published in $1893 .{ }^{17}$ This terminology - "à l'européenne" - was then taken over by Alfred Foucher (1894: 348) and given preeminence in his pioneering writings on Buddhist art (e.g. 1905: 49 n.1; 1909: 26 Plate 4).

At first sight, this designation may be perceived as a sign of naive and incipient research on Buddhist iconography. But it also reflects the Eurocentric biases of Western scholars in their criteria of classification. Moreover, this designation
"European posture" seemed inappropriate to South Asian scholars, such as Ananda Coomaraswamy, one of the most prominent at the time. The latter preferred to substitute a new Sanskrit compound of his own creation: "pralambapāda àsana," which was later transformed to pralambapādāsana, literally "the sitting posture with two legs pendant" (Coomaraswamy 1926: 124; 1965 [1927]: 76, 96). This designation, it must be stressed, has no textual basis and was promoted as an indigenous response to Foucher's European biases. Subsequently, the disciples of these great pioneers in the study of Buddhist art continued to use one terminology ("the European posture") or another (pralambapādāsana). ${ }^{18}$ Foucher's preferred terminology, somewhat captured by Coomaraswamy's artificial Sanskrit compound, has been followed by a whole generation of French historians who paved the way for the study of archaeology in Thailand. George Cœdès (e.g. 1927: 8) and Pierre Dupont (e.g. 1959: 266-280) were certainly amongst the most influential.

In addition to these two phrases, other Sanskrit terms were used to refer to this posture, such as bhadrāsana, maitreyāsana, sattvāsana, and, sometimes, paryañkāsana (e.g. Mallmann 1948: 256-257; Liebert 1986: 36, 216, 225; Terentyev 2004: 47). However, some of these asānas or sitting postures are pure inventions or neologisms of art historians (e.g. maitreyāsana). The correct interpretations of others are somewhat problematic; paryankāsana, which is also perceived as the crossed-legs posture, is one such example (Auboyer 1949: 194-195). ${ }^{19}$ For our purpose, the term bhadrāsana would seem to be a better choice, since unlike pralambapādāsana, it has a textual basis. For instance, the Sanskrit text named Vajrāvalī gives the following definition for the term bhadrāsana: "Rijucaraṇadvayamuccāsanastho dhārayediti bhadrāsanam" which has been translated as: "In the bhadrāsana, the two legs should dangle down from a raised seat straightway" (Bhattacharyya 1981: 76-77). ${ }^{20}$ Because of its demonstrable textual basis from the Pāla period onwards, the term bhadrāsana, in my opinion, should be favored over pralambapādāsana or any other Sanskrit terms when referring to this posture. Moreover, it seems to satisfactorily capture the royal symbolism conveyed by these buddha images. $^{21}$

\section{A "ROYAL POSTURE"}

My contention is that the enthroned buddha images with legs pendant invoke the royal authority in affirming the primacy of the or $a$ buddha (whichever one it may be). This posture is the one which best fits princes and kings alike because it marks their preeminence over their subjects. Note that Lucien Fournereau, the first European to have been to Nakhon Pathom and seen one of the relief fragments of the First Sermon discussed above by Woodward (Figure 7), did not 


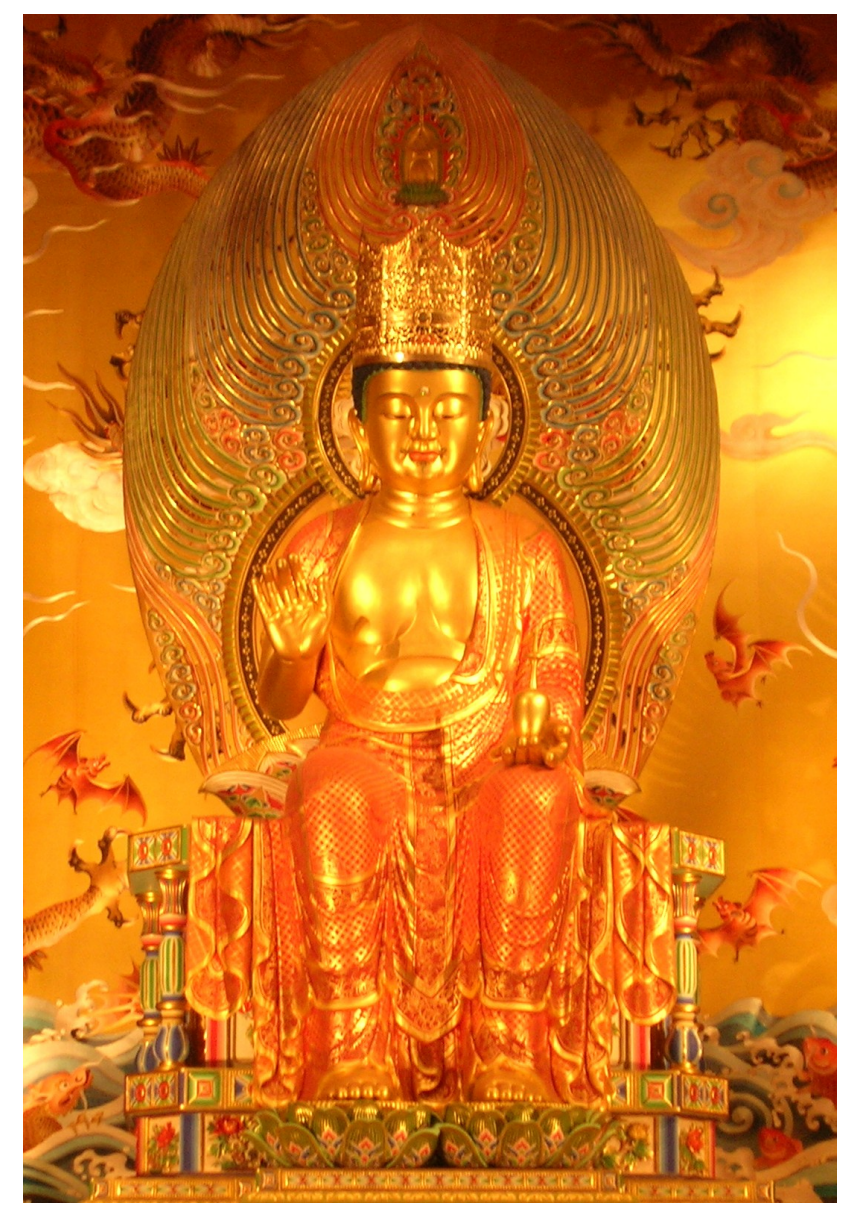

Figure 15: Pendant-Legged Buddha Maitreya with a Removable Crown and a Water Bottle, Copper Alloy, $21^{\text {st }}$ Century, Tooth Relic Temple, Singapore

identify the scene and the Buddha Śākyamuni as such but simply as "a king seated on a throne [and] speaking to an audience" (1895: 121; also Hennequin 2009: 138-139 Figures 2-3). Actually, this mode of sitting was already fairly common in Gandhāra in the time of the Kuṣānas and was not only allotted to kings (Figure 9) but to bodhisattvas and other divinities as well, perhaps echoing Greek and Parthian traditions (Rosenfield 1967: 186-188).

In addition, I also tend to think that this iconographic convention in Indian art preceded the fashion to represent actual crowned buddha images and perhaps filled the gap after the so-called "aniconic phase" with the "empty throne" (Figure 10), symbol par excellence of the Buddha's presence as a spiritual or earthly king. The underlying idea remains that the buddhas are made king in this world through the symbolism of the throne, especially the "lion throne" or simhāsana (Auboyer 1949: 34-35, 108-110). According to Claudine Bautze-Picron, a crucial moment in the life of the Buddha Śăkyamuni seems to have been his sojourn on Mount
Meru - after performing the Great Miracle at Śāvastī where he sat on Indra's throne and taught to the gods in Trāyastrimśa. By occupying the seat of the "king of the gods" (Indra), she argues that Śākyamuni was able to endorse the royal function of this deity and rule over the universe (Bautze-Picron 2010). The iconography related to this sequence of narrative events becomes particularly evident in some late fifth or sixth century reliefs from the Mahārāșțra caves in India, (e.g. Figure 11) and later in Dvāravatī art (Figures 12-13).

Moreover, it seems that the iconography of buddhas seated in bhadrāsana declines precisely at the time when the tradition of the bejeweled buddhas starts to emerge in Indian art. Indeed, the crowned and adorned buddha images materialize relatively late in the first millennium during the Pāla-Sena period (eighth to twelfth centuries C.E.). ${ }^{22}$ But certain Pāla images, as well as models from Kashmir, seem to overlap these two traditions; here the buddhas are sitting enthroned with legs pendant and at the same time are decorated with a crown (Bourda 1949: 310-311 Figure 5; Bautze-Picron 2010: 90-91 Figures 84-85) (Figure 14). It is this tradition which can still be found today, such as in the modern iconography of Buddha Maitreya (Figure 15).

To conclude, it is assumed that royal symbolism is incontestably attached to this peculiar iconography. The difficulties scholars seem to face in identifying individual buddha images in bhadrāsana, for example, would reinforce the notion that a real identity binds all the buddhas together, be it Śākyamuni, Maitreya or Vairocana. This common identity, I believe, is fundamentally that of royalty. Therefore, and for the sake of precision, it would be best to discard the use of the "European posture" when addressing this iconography in future writings. While the term pralambapādāsana may be conventionally used in pure descriptive matters, it should be kept in mind that this is a neo Sanskrit term found only in later art historical sources and has no intrinsic meaning. Ancient Buddhist iconographic treatises refer only to the term bhadrāsana and so its use seems more justified and preferable. It may also appear to reflect the royal component - an essential element. The other Sanskrit expressions to describe this seated posture may be more problematic because they too often bias scholarly interpretation. Alternatively, it may be proposed to label the buddhas under scrutiny seated either "in majesty" or "royally."

\section{ACKNOWLEDGEMENTS}

I am grateful to Claudine Bautze-Picron, Peter Skilling, Nancy Tingley and Hiram Woodward for their valuable comments on a preliminary version of this paper, to Donald Stadtner and Wesley Clarke for their kind assistance in editing the English and to Pierre Pichard for his permission to reproduce the Figures $2 \mathrm{a}-\mathrm{b}$. 


\section{NOTES}

1. I will use lower caps throughout when not specifying to a particular "buddha."

2. In the course of my own research, I did not notice any significant articles or monographs previously devoted to this iconography aside from M.G. Bourda (1949), who only deals with Indian images. With regards to Thai scholarship, I should mention the modest works of Sitthichai Thawipon (2530 [1987]) and more recently of Chotima Chaturawong (2009) from Silpakorn University. Surprisingly, the recent Guimet catalogue published for the Dvāravatī exhibition (Baptiste and Zéphir 2009) failed to dedicate a special section on the subject. This short paper is therefore a preliminary attempt to fill the gap in the scholarship and shall be followed by more extensive contributions (e.g. Revire, forthcoming).

3. The Thai formulation "nang hoi phrabat" which is used to indicate this posture does not say another thing: literally "seated pendant-legged." It is accompanied sometimes by the usual expression "baeb yurop," i.e. "in the European fashion" which I will discuss below.

4. In later periods, buddha images of Sākyamuni with legs pendant often occur in conjunction with the offering of the honey or madhu by the monkey at Vaiśāli or the retreat in the Pārileyyaka forest, but these fall outside the discussion of Dvāravatī art.

5. I have addressed these issues at length in my Masters thesis (2008), in a recent article (2010) and paper (2011).

6. Many of these characteristics are conceptual rather than physical and hence are not visually apparent.

7. For a thorough analysis of these images, see Revire 2008 and Revire 2010.

8. Dupont recounts, but did not illustrate with a picture, another pendant-legged buddha from Phnom Dà in Cambodia, similar to the Sòn Tho buddha image, that is reported missing (1955: 190-191). Interestingly, a very similar image said to have been acquired in 1954 was recently noticed in the property of a London dealer who may remain anonymous. I must thank Hiram Woodward for bringing this image to my attention. Peter Skilling speaks of a similar, but smaller sized, buddha $(21 \mathrm{~cm})$ with a "ye dharma " inscription on the back, having apparently been found in the province of Quáng Nam in early twentieth century. Unfortunately, it was never published or photographed and is now untraceable (2003: 285 n. 33). On the other hand, an unusual model showed up in a recent exhibition in America, but its exact provenance is unknown (Tingley 2009b: 114 Plate 38). This buddha image, never published before and belonging to a private collection, seems to show an interesting blending of both the Dvāravatī iconographic type and the Mekong Delta art style. Could one of these aforementioned buddha statues kept in private collections be the one reported missing by Dupont?

9. I exclude from this study the central buddha image enshrined at Candi Mendut, Java, on the basis that the two hands display a different preaching gesture (dharmacakramudrā or dharmacakrapravartanamudrā). I believe it also postdates (ca. $8^{\text {th }}-9^{\text {th }}$ centuries) the images under consideration in this paper and assume that it draws its inspiration elsewhere in a different artistic tradition from India.

10. As far as I know, there is possibly the exception of two reliefs. One low-relief from Nāgārjunakoṇḍa, Andhra Pradesh, while the other, in very high-relief, is presumably from North-West India and is today kept in storage of the Asian Art Museum in Berlin (Revire, forthcoming Fig. $1 \mathrm{n}$. 2).

11. John Huntington speculates that the most common mudrā type at Ajantā and throughout the caves of western India is, in fact, an "esoteric" variant of this gesture (Huntington and Chandrasekhar 2000).

12. There are a few common "trans-regional" clay tablets, showing this hand gesture (dharmacakramudrā), that are found not only in India but also in Central Thailand (Skilling 2009: 111; Baptiste and Zéphir 2009: 196 Figure 5), the Malay Peninsula (Jacq-Hergoualc'h 2002: Figures 126, 190, 195) and in Burma (Luce 1970, III: Plates 50-53). There is also the notable exception of a little bronze seated buddha with crossed-legs, and with the same teaching gesture, said to have been found in Kalasin province, Thailand (Fine Arts Department 2009: 59 Figure 37). However, these images, stylistically dated from the Pāla period, may be too late for our purpose and do not strictly belong to the Dvāravatī tradition.

13. Here I may go against certain frequent assertions such as in Chotima Chaturawong (2009).

14. The work which presumably influenced this Dvāravatī relief does not need to have come from China proper. It could have easily been carried by a Chinese monk travelling back from India to China and, therefore, considered authentically Indian (Woodward, personal communication 2011). For a fuller account of the fairly extensive interaction of Buddhist monks between India and East Asia circa the seventh and eighth centuries via the Southern Seas, see Woodward (1988); for another fresh discussion regarding their possible role as "transmitter" of new iconographic idioms, see Revire (Forthcoming).

15. Recently, Pierre Baptiste has proposed a much later date for the buddhas from Wat Phra Men, Nakhon Pathom, to the ninth century, or even later to the Bayon period but, for the reasons stated above, his argument is not really convincing (Baptiste and Zéphir 2009: 223). 


\section{REVIRE: RECONSIDERATIONS ON PENDANT-LEGGED BUDDHA IMAGES}

16. See also Skilling (2009: 107-108) for a similar discussion concerning the problem of terminology vis-à-vis "votive tablets" or "clay sealings."

17. Only reference to the second reprint is made: "In der Regel wird er stehend oder - wenn auch nicht ausschließlich - nach europäischer Art sitzend dargestellt" (1920: 161); see also Burgess (1972 [1901]: 186) for the English translation. I am grateful to Claudine Bautze-Picron for having checked the occurrence in the German edition.

18. In the same vein, recall the strong contentions concerning Foucher's and Coomaraswamy's proponents in connection with the supposed place of origin of the first "anthropomorphic" buddha image. The former were in favor of a Greek influence and located its appearance in Gandhāra. The latter were in favor of an Indian origin and placed the first buddha image in Mathurā. This is still an ongoing debate amongst scholars.

19. Perhaps enhancing the confusion is the fact that the term paryanka (in Sanskrit), pallañka (in Pāli) or ballang (in Thai) - which gave the word "palanquin" in English - also refers to a kind of couch specially designed for kings or high dignitaries.

20. The text Kriyassamgraha (Chapter 6), composed in Sanskrit before 1216 and in Tibetan circa 1280-1292, also mentions various bodhisattvas seated in bhadrāsana. In the Tibetan version of the text, this āsana is defined as "rkang pa gnyis drang por gdan mthon po la gnas nas gzung bar bya'o," which Skilling roughly translates as "having sat on a high seat, the two legs are to be held straight, that is bhadrāsana" (Personal communication, 2010). For an abridged English translation of this section of the text (after the Tibetan version), see Skorupski (2002: 97).

21. Names like Rāmabhadra - where bhadra is joined with the quintessentially royal name Rāma and other compounds involving bhadra, suggest that the term may well have carried "royal" connotations in certain contexts. I wish to thank Arlo Griffiths for this observation. In the same vein, it was brought to my attention recently that Sao Htun Hmat Win's book Seats, Postures, Vehicles and Historical Sketch of Burmese Buddhist Iconography, refers to bhadrāsana as the "majestic seat, glorious seat." Unfortunately, I was unable to consult this publication.

22. Bautze-Picron considers the crowned buddha image, preserved at the Asia Society in New York and dated 714 by inscription, as one of the first pieces of evidence for the existence of this artistic tradition in Buddhist Art (2010: 5062, 66-67 Figure 59). See also Huntington and Bangdel (2003: 84-85).

\section{REFERENCES}

Auboyer, Jeannine. 1949. Le trône et son symbolisme dans l'Inde ancienne. Paris: Presses universitaires de France.

Baptiste, Pierre and Thierry Zephir (eds.). 2009. Dvāravatī : aux sources $d u$ bouddhisme en Thaillande, (Exhibition Catalogue). Paris: Réunion des Musées nationaux.

Bautze-Picron, Claudine. 2010. The Bejewelled Buddha from India to Burma: New Considerations. New Delhi/ Kolkata: Sanctum Books.

Bhattacharyya, D.C. 1981. Vajrāvalī-nāma-maṇḍalopāyikā of Abhayākaragupta. In Michel Strickmann (ed.), Tantric and Taoist Studies in Honour of R.A. Stein, Vol. I, pp. 70-95. Bruxelles: Institut belge des Hautes études chinoises.

Bourda, Maria-George. 1949. Quelques réflexions sur la pose assise à l'européenne dans l'art bouddhique. Artibus Asiae 12: 302-313.

Burgess, James. 1972. Buddhist Art in India. Translated from the "Handbuch" of Albert Grünwedel, by Agnes C. Gibson. New Delhi: S. Chand \& Co. (1st German Edition 1893; 1st English Edition 1901).

Carter, Martha L. 1990. The Mystery of the Udayana Buddha. Supplemento n. 64 agli Annali 50-3. Napoli.

Chotima Chaturawong. 2009. Indo- Thai Cultural Interaction: Buddha Images in Pralambapadasana. In Lipi Ghosh (ed), Connectivity \& Beyond: Indo-Thai Relations Through Ages, pp. 55-77. Calcutta: The Asiatic Society.

Cœdès, George. 1927. Siamese votive tablets. Journal of the Siam Society 20: 1-23.

Coomaraswamy, Ananda K. 1926. Pour comprendre l'art hindou. Paris: Bossard.

1965. History of Indian and Indonesian Art. New York: Dover Publications. (Reprint, 1st Edition 1927).

De Mallmann, Marie-Thérèse. 1948. Introduction à l'étude d'Avalokiteçvara. Paris: Civilisations du Sud.

Dhanit Yupho. 1967. Quartzite Buddha Images of the Dvāravatī Period. Bangkok: Fine Arts Department.

Dupont, Pierre. 1955. La statuaire préangkorienne. Ascona: Artibus Asiae Supplementum.

1959. L’archéologie mône de Dvāravat̄̄, 2 vols. Paris: Publication de l'École française d'Extrême-Orient. 


\section{BULLETIN OF THE INDO-PACIFIC PREHISTORY ASSOCIATION 31, 2011}

Fine Arts Department of Thailand. 2009. Silapa thawarawadi tonkamnoet phutthasin nai prathet thai [Dvāravatī Art: The Early Buddhist Art of Thailand]. Bangkok: Fine Arts Department. (Text in Thai and English).

Fontein, Jan. 1990. The Sculpture of Indonesia, (Exhibition Catalogue). New York: Abrams. (Includes essays by R. Soekmono and E. Sedyawati).

Foucher, Alfred. 1894. L'art bouddhique dans l'Inde. D'après un livre récent. Revue de l'Histoire des Religions 30: 319 -371 .

1905. Étude sur l'iconographie bouddhique de l'Inde d'après des textes inédits. Paris: Ernest Leroux.

1909. Le 'Grand Miracle' du Buddha à Çrâvastî. Journal asiatique 13: 5-77.

Fournereau, Lucien. 1895. Le Siam ancien, archéologie, épigraphie, géographie, Vol. I. Paris: Ernest Leroux.

Frédéric, Louis. 2001. Les dieux du bouddhisme. Guide iconographique. Paris: Flammarion. (2nd Reprint ; 1st Edition 1992).

Grünwedel, Albert. 1920. Buddhistische Kunst in Indien. Berlin/Leipzig: Vereinigung Wissenschaftlicher Verleger. (2nd Reprint, 1st Edition 1893)

Härtel, Herbert, M. Yaldiz, and Metropolitan Museum of Art (eds.). 1982. Along the Ancient Silk Routes, Central Asian Art from the West Berlin State Museums, (Exhibition Catalogue). New York: Metropolitan Museum of Art.

Hennequin, Laurent. 2009. Nakhon Pathom au temps de Lucien Fournereau. In Pierre Baptiste and Thierry Zéphir (eds.), Dvāravatī: aux sources du bouddhisme en Thaïlande, pp. 137-143. Paris: Réunion des Musées nationaux.

Huntington, John C. and Dina Bangdel. 2003. The Circle of Bliss: Buddhist Meditational Art, (Exhibition Catalogue). Chicago: Serindia Publications.

Huntington, John C. and Chaya Chandrasekhar. 2000. The Dharmacakramudrā Variant at Ajanta: An Iconological Study. Ars Orientalis 30-I: 33-39.

Jacq-Hergoualc'h, Michel. 2002. The Malay Peninsula. Crossroads of the Maritime Silk Road (100 B.C.-1300 A.D.). Leiden: Brill.
Liebert, Gösta . 1986. Iconographic Dictionary of the Indian Religions. Hinduism-Buddhism-Jainism. Delhi: Sri Satguru Publications. (2nd Edition; 1st Edition 1976)

Lorrillard, Michel. 2008. Pour une géographie historique du bouddhisme au Laos. In Yves Goudineau and Michel Lorrillard (eds), Recherches nouvelles sur le Laos, pp. 113-181. Ventiane-Paris: École française d'ExtrêmeOrient.

Luce, Gordon H. 1985. Phases of Pre-Pagan Burma, Language and History, 2 vols. Oxford: Oxford University Press.

Malleret, Louis. 1963. L'Archéologie du Delta du Mékong. T.IV : le Cisbassac. Paris: Publication de l'École française d'Extrême-Orient.

McNair, Amy. 2007. Donors of Longmen: Faith, Politics, and Patronage in Medieval Chinese Buddhist Sculpture. Honolulu: University of Hawai'i Press.

Moore, Elizabeth H. 2007. Early Landscapes of Myanmar. Bangkok: River Books.

Revire, Nicolas. 2008. Introduction à l'étude des bouddhas en pralambapādāsana dans l'art de Dvāravatī : le cas du Wat Phra Men - Nakhon Pathom, 2 vols. Unpublished Masters Thesis, University Paris 3-Sorbonne-nouvelle.

2010. Iconographical Issues in the Archeology of Wat Phra Men, Nakhon Pathom. Journal of the Siam Society 98: 75-115.

2011. Maitreya or Not? Understanding Bhadrāsana Buddhas in Southeast Asia during the First Millennium CE. Paper presented at the XVIth Congress of the International Association of Buddhist Studies, June 2025, 2011, Taiwan.

Forthcoming. New Perspectives on the Origin and Spread of Bhadrāsana Buddhas throughout Southeast Asia (7th-8th centuries). Paper submitted at the 13th Conference of the European Association of Southeast Asian Archaeologists, September 27-October 1, 2010, Berlin.

Rhie, Marylin M. 1988. Interrelationships between the Buddhist Art of China and the Art of India and Central Asia from 618-755 A.D. Supplemento n. 54 agli Annali, 48-1, Napoli.

Rosenfield, John M. 1967. The Dynastic Arts of the Kushans. Berkeley and Los Angeles: University of California Press. 
Sitthichai Thawipon. 2530 [1987]. Phra phuttharup pratap nang hoi phrabat nai samai thawarawadi [Images of Seated Buddhas with Pendant Legs in the Dvāravatī period]. Unpublished Masters Thesis, Silpakorn University, Bangkok. (in Thai)

Skilling, Peter. 2003. Traces of the Dharma: Preliminary Reports on Some Ye Dhammā and Ye Dharmā Inscriptions from Mainland South-East Asia. Bulletin de l'École française d'Extrême-Orient 90-91: 273-287.

2009. Des images moulées au service de l'idéologie du mérite. In Pierre Baptiste and Thierry Zéphir (eds.). Dvāravatī : aux sources du bouddhisme en Thaïlande, pp. 107-113. Paris: Réunion des Musées nationaux.

Skorupski, Tadeusz. 2002. Kriyāsamgraha: Compendium of Buddhist Rituals, An Abridged Version. Tring: The Institute of Buddhist Studies.

Terentyev, Andrey. 2004. Buddhist Iconography Identification Guide. St. Petersbourg: Carleton Copeland. (English Edition).

Tingley, Nancy (ed.). 2009a. Arts of Ancient Viet Nam: From River Plain to Open Sea. New Haven and London: Yale University Press.

. 2009b. buddhas. (Exhibition Catalogue). Sacramento: Crocker Art Museum.

Wong, C. Dorothy (ed.). 2008. The Hōryūji Reconsidered. Newcastle: Cambridge Scholars Publishing.

Woodward, Hiram W., Jr. 1988. Southeast Asian Traces of the Buddhist Pilgrims. Muse, Annual of the Museum of Art and Archaeology 22: 75-91.

2003. The Art and Architecture of Thailand, From Prehistoric Times through the Thirteenth Century. Leiden-Boston: Brill. 